\title{
ECONOMY
}

\section{ANALYSIS OF THE CURRENT SITUATION OF INSURANCE MARKET AND CREDIT INSURANCE IN RA}

\author{
Gohar Voskanyan, Ph.D. in economics \\ Yerevan, Republic of Armenia \\ Junior scientific researcher at the National Academy of RA, \\ Institute of Economics named after M. Kotanyan
}

DOI: https://doi.org/ 10.31435/rsglobal_ws/30112018/6234

\section{ARTICLE INFO}

Received: 09 September 2018

Accepted: 21 November 2018

Published: 30 November 2018

\section{KEYWORDS}

insurance market,

insurer,

insurance premium

insurance indemnity,

credit insurance,

compulsory insurance

\begin{abstract}
The Armenian insurance market has undergone major changes in the transition to a market economy. Growth tendencies were observed in almost all insurance indicators. At present, the RA Central Bank is the body overseeing the financial system of RA. The positive shifts in the insurance market are partially conditioned by its activities. The article presents the main directions of the activities of insurance companies in RA. Insurance premiums and insurance indemnities have undergone comparative analysis. In a number of countries the insurance is one of the most important prerequisites for the provision of agricultural loans through which banks try to mitigate their credit risk. Agricultural insurance is not implemented in the Republic of Armenia, which negatively affects the stability and development of the sector. Taking into account the advantages of compulsory insurance and the current socio-economic conditions created in Armenia, the article recommends to implement compulsory insurance of agricultural credits. The necessity of introduction of credit insurance in the RA agrarian sphere has been justified, the reasons of non-implementation of agricultural credit insurance has been raised, and the main results expected when implementing agricultural credit insurance has been presented.
\end{abstract}

Citation: Gohar Voskanyan. (2018) Analysis of the Current Situation of Insurance Market and Credit Insurance in Ra. World Science. 11(39). doi: 10.31435/rsglobal_ws/30112018/6234

Copyright: (C) 2018 Gohar Voskanyan. This is an open-access article distributed under the terms of the Creative Commons Attribution License (CC BY). The use, distribution or reproduction in other forums is permitted, provided the original author(s) or licensor are credited and that the original publication in this journal is cited, in accordance with accepted academic practice. No use, distribution or reproduction is permitted which does not comply with these terms.

Introduction. The insurance market is a unique socio-economic environment where the insurance contract is the object of sale and purchase. Until 2011 all groups of insurance classes in Armenia were conducted on a voluntary basis, after which liability insurance based on the use of land vehicles a mandatory policy was performed. With the introduction of compulsory insurance, the insurance market of Armenia entered a new stage of development and growth was observed in almost all indicators of insurance. Since 2006, the Central Bank of Armenia has been the supervisory body in the insurance market and one can say with confidence, that it implements its supervisory functions quite effectively. According to the official website of the Central Bank of Armenia, insurance companies operating in the insurance market of Armenia are "ISG" Insurance, "Armenia Insurance", "Ingo Armenia", "Armenian Motor Insurers' Bureau", "Export Insurance Agency of Armenia" , "Nairi Insurance", "Reso", "Rosgosstrakh-Armenia", "Sil Insurance" companies. [1] 
According to the Law of the Republic of Armenia "On Insurance and Insurance Activities" the types of insurance are:

1. Non-life insurance,

2. Life Insurance,

3. Reinsurance. [2]

Research results. Currently, insurance companies carry out only non-life insurance. Lack of life insurance is explained mainly by the lack of solvent demand for this type of insurance. We have presented the summary of insurance premiums analysis in Table 1. According to the data of the Arminfo agency, as of December 31, 2017, the insurance companies of Armenia collected 34,94,337.8 thousand AMD insurance premium on non-life insurance. [3] For comparison we would like to mention that , during the same period, 2234424 million USD insurance premium on non-life insurance was recruited worldwide[4], ie the insurance premiums collected in the Republic of Armenia formed only $0.0032 \%$ of total insurance premiums (the calculations were made at the exchange rate of $1 \mathrm{USD}=488.57$ drams). $54.41 \%$ of total premiums collected in the RA was for compulsory motor third party liability insurance (CMTPL), 20.29\% was for health insurance, $7.57 \%$ was for property insurance against fire and natural disasters, $5.57 \%$ was for land transport insurance. Insurance premiums collected for the rest of the insurance group of classes constitute the smallest part (less than 2\%). [5] An interesting regularity is observed: most of the insurance premiums are those insurance group of classes that are compulsory (CMTPL, health insurance within the frames of social package) or on the basis of "voluntary-mandatory" insurance ("mandatory-voluntary" insurance of pledged property). The calculations show that Ingo Armenia CJSC is the first in the volume of collected insurance premiums - 27.2\%, Rosgosstrakh Armenia CJSC - 26.8\%, is in the second place, and the third place is occupied by "Armenia Insurance" CJSC- 6.3\%:

Table 1. Insurance premium analysis indicators, 2017*

\begin{tabular}{|l|l|l|l|l|}
\hline \multirow{2}{*}{ Continent } & \multicolumn{2}{|c|}{ Insurance Premium } & \multirow{2}{*}{$\begin{array}{c}\text { Share of insurance } \\
\text { premium in GDP (\%) }\end{array}$} & $\begin{array}{c}\text { Insurance premium } \\
\text { per resident, USD }\end{array}$ \\
\cline { 2 - 5 } & $\begin{array}{c}\text { Total } \\
\text { mln. USD) }\end{array}$ & Share (\%) & & 23.9 \\
\hline Armenia & 71.5 & 0.0032 & 0.63 & 686 \\
\hline Europe & 621171 & 27.8 & 2.68 & 123 \\
\hline Asia & 546998 & 24.5 & 1.93 & 297 \\
\hline In the world & 2234424 & 100 & 2.8 & \\
\hline
\end{tabular}

*This table is made by the author.

Insurance premiums collected in the Republic of Armenia made only 0.63\% of GDP (5 568 901500 thousand AMD) [6], and this indicator on the whole world level is 2.8\% [7]. That is, with this indicator Armenia is small by 4.4 times. The insurance premium per resident is 11704 AMD (23.9 USD). The basis for this calculation was the number of population in Armenia-2986.1 thousand people as of January 1, 2017 [8] and this indicator on the world level is 297 USD [9]. In other words, with this index Armenia is behind the average world level about 12.4 times.

The insurance indemnities given by the insurance companies of Armenia are 17762648.7 thousand AMD, the majority of which - 11680335.5 thousand AMD (65.76\%) was the share of compulsory motor third party liability insurance (CMTPL). The second place is occupied by health insurance- 4025142.3 thousand AMD (22.66\%), and third place is occupied by the land transport insurance - 1155358.4 thousand AMD (6.5\%).

If "Ingo Armenia" was in the first place with the volume of collected insurance premiums, then "Rosgosstrakh Armenia" was in the first place with insurance indemnities-5305169.0 AMD (29.9\%). The "Armenia-Insurance" company is in the last place with both the volume of collected insurance premiums and the amount of indemnities paid- 1055834.0 thousand AMD (5.9\%). [10]

General insurance premiums, insurance payments and reinsurance premiums collected in the Republic of Armenia for 2015-2017 are presented in Chart 1. The chart shows that the abovementioned indicators have had growth trends. As compared with 2015, in 2017 the insurance premiums increased by $11 \%$, insurance payments by $31 \%$, and reinsurance premiums by $20 \%$. 


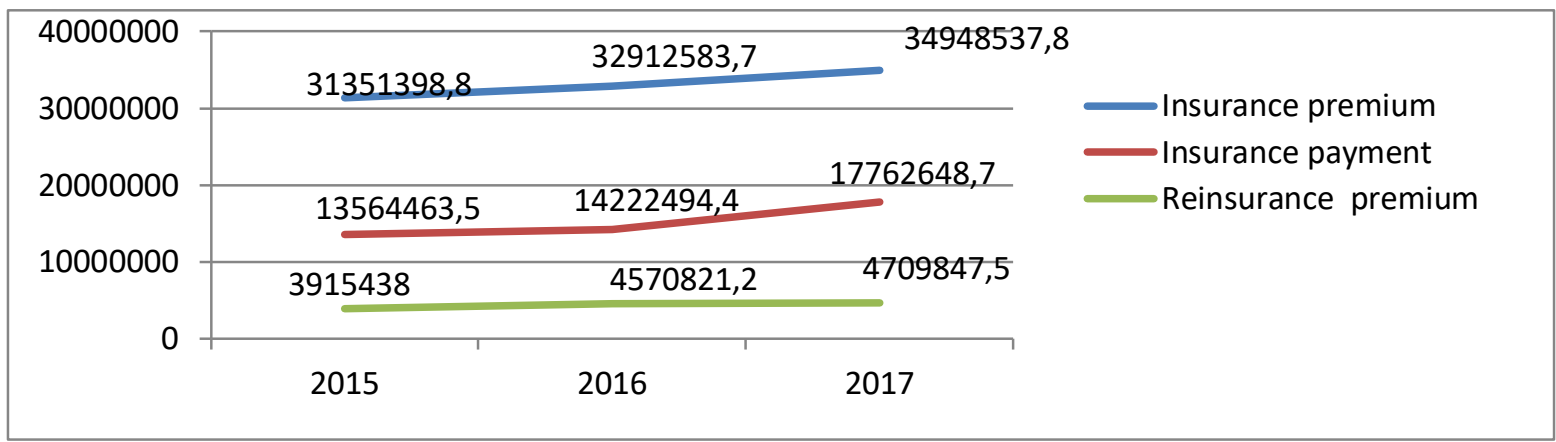

Fig. 1. Dynamics of insurance premiums, insurance payments and reinsurance premiums for 2015-2017 (thousand AMD)

Being a separate link in the financial market, insurance has great leverage on maintaining the stability of the real sector of the economy as well as other sectors of the financial market. At present Armenia's legislation prohibits the combination of banking and insurance activities, although in a number of countries banks and insurers are involved in both types of activities simultaneously. As in other areas of business, insurers can effectively secure banking risks, starting from encashment and operating, ending with credit and investment. The existing isolation of banking and insurance sectors in the financial market of Armenia is fragmented, as the necessity of the joint activity and mutual benefit, in terms of functionality, are clear to the representatives of two institutional structures of the financial market. [11]

In our previous studies, we have mentioned that agricultural credit insurance can be one of the most important preconditions for ensuring the stability and development of the agrarian sector as well as the overall financial system. Lending and insurance are closely interconnected. On the one hand, through insurance, rural farms with credit can manage their incomes more efficiently, (fluctuations of which are especially caused by unpredictable weather conditions). On the other hand, when starting agricultural activities, when a decision has been made to sign a farming contract at the same time, it is likely that farmers will not have enough financial means to obtain seeds, fertilizers and other production means and also pay for insurance. Acquisition of insurance in this sense may be inconvenient. A loan can also be an important tool for mitigating the risk of income loss. Households can borrow a loan for the purchase of food and other essential goods, as well as for the purchase of production facilities for agricultural activities, and repay the loan after harvest. Although credit and insurance have the same primary impact, they complement each other. Insurance primarily involves risks that are rarely occurring, but generate substantial losses, while the self- insurance gained through savings and loans involves risks that are frequent but cause minor damages. That is why insurance and lending are important tools in terms of improving living conditions and income stabilization. In developing countries where the insurance market is not so developed, farmers usually apply to traditional self-insurance. Thus, they can create reserves and financial assets to overcome difficulties during hard time. [12]

Voluntary and compulsory insurance may be implemented in the Republic of Armenia. Voluntary insurance is the insurance which is implemented via signing an insurance contract between the insurer and insured person on a voluntary basis. Compulsory insurance is a relationship with the insurer, independent of the will of the insurer, the types, terms and procedures of which are regulated by the Civil Code of the Republic of Armenia, the Law of the Republic of Armenia "On Insurance and Insurance Activities" and the Compulsory Insurance Laws. The law can anticipate cases of life and non-life insurance of citizens at the expense of means allocated by the state budget (obligatory state insurance). [13]

Conclusions. From the analysis of the statistical data it has become clear that in 2015-2017, all the credit insurance indicators were 0 . In other words, no credit insurance is implemented in Armenia. Agricultural loans in the loan portfolio of RA are particularly vulnerable and the effective management of risks connected with them may have a great impact on the effectiveness of agrarian sector. Taking into account the low level of insurance culture prevalence among farmers, as well as insufficient awareness of insurance, we offer the compulsory method of agricultural credit insurance in Armenia. The latter has a number of advantages over voluntary insurance. In particular, in case of compulsory insurance, the risk of bad sampling will be reduced, and insurers will have a more balanced portfolio of contracts. 


\section{REFERENCES}

1. https://www.cba.am/am/SitePages/fscfoinsuranceorganizations.aspx

2. «Insurance and Insurance Activities», RA Law 2007, Article 7

3. The Chart has been made based on data by ARMINFO agency, Information Company, Ranking of Insurance Companies of RA on 31.12.2017, N "52" 06.02.2017, p 45, p 18

4. Swiss Re Institute, Sigma, World Insurance in 2017: solid, but mature life markets weigh on growth, N 3/2018, p 51, p. 44, http://www.swissre.com/library/publication-sigma/sigma_3_2018_en.html

5. ARMINFO, Information Company, Ranking of Insurance Companies of RA on 31.12.2017, N "52" 06.02.2017, 45p, p 19

6. https://www.armstat.am/am/

7. Swiss Re Institute, Sigma, World Insurance in 2017: solid, but mature life markets weigh on growth, N 3/2018, p 51, p. 46, http://www.swissre.com/library/publication-sigma/sigma_3_2018_en.html

8. https://www.armstat.am/file/article/nasel_01.01.2017.pdf

9. Swiss Re Institute, Sigma, World Insurance in 2017: solid, but mature life markets weigh on growth, N 3/2018, p 51, p. 45, http://www.swissre.com/library/publication-sigma/sigma_3_2018_en.html

10. ARMINFO, Information Company, Ranking of Insurance Companies of RA on 31.12.2017, N "52" 06.02.2017, p 45, p 20

11. www.irtek.am/views/act.aspx?aid=11711

12. FARM RISK MANAGEMENT for AFRICA PROJECT (FaRMAf), Linking crop insurance and rural credit, 19p., p. 3 https://agritrop.cirad.fr/569644/1/document_569644.pdf

13. Civil Code of the Republic of Armenia, https://www.arlis.am/DocumentView.aspx?docid=74658

1998, Article 983, 